\title{
Summer ozone in the northern Front Range metropolitan area: weekend-weekday effects, temperature dependences, and the impact of drought
}

\author{
Andrew J. Abeleira and Delphine K. Farmer \\ Department of Chemistry, Colorado State University, Fort Collins, CO, 80523, USA \\ Correspondence to: Delphine K. Farmer (delphine.farmer@colostate.edu) \\ Received: 19 February 2017 - Discussion started: 22 February 2017 \\ Revised: 24 April 2017 - Accepted: 1 May 2017 - Published: 2 June 2017
}

\begin{abstract}
Contrary to most regions in the US, ozone in the northern Front Range metropolitan area (NFRMA) of Colorado was either stagnant or increasing between 2000 and 2015, despite substantial reductions in $\mathrm{NO}_{x}$ emissions. We used available long-term ozone and $\mathrm{NO}_{x}$ data in the NFRMA to investigate these trends. Ozone increased from weekdays to weekends for a number of sites in the NFRMA with weekend reductions in $\mathrm{NO}_{2}$ at two sites in downtown Denver, indicating that the region was in a $\mathrm{NO}_{x}$-saturated ozone production regime. The stagnation and increases in ozone in the NFRMA are likely due to a combination of decreasing $\mathrm{NO}_{x}$ emissions in a $\mathrm{NO}_{x}$-saturated environment and increased anthropogenic volatile organic compound (VOC) emissions in the NFRMA. Further investigation of the weekend-weekday effect showed that the region outside of the most heavily trafficked Denver area was transitioning to peak ozone production towards $\mathrm{NO}_{x}$-limited chemistry. This transition implies that continued $\mathrm{NO}_{x}$ decreases will result in ozone being less sensitive to changes in either anthropogenic or biogenic VOC reactivity in the NFRMA. In contrast to anthropogenic VOCs, biogenic VOCs are unlikely to have increased in the NFRMA between 2000 and 2015, but are temperature dependent and likely vary by drought year. Ozone in the NFRMA has a temperature dependence, albeit smaller than many other US locations, consistent with biogenic VOC contributions to ozone production in the region. We show that while ozone increased with temperature in the NFRMA, which is consistent with a $\mathrm{NO}_{x}$-saturated regime coupled to temperature-dependent VOCs, this relationship is suppressed in drought years. We attribute this drought year suppression to decreased biogenic isoprene emissions due to long-term drought stress. Thus, while anthropogenic $\mathrm{NO}_{x}$ and VOCs
\end{abstract}

likely dominate ozone production regimes in the NFRMA, biogenic VOCs may also impact regional ozone and its temperature dependence.

\section{Introduction}

Tropospheric ozone $\left(\mathrm{O}_{3}\right)$ is detrimental to human health, impacting the frequency of asthma attacks, cardiovascular disease, missed school days, and premature deaths. Based on these impacts, the Environmental Protection Agency (EPA) projects that reducing the $\mathrm{O}_{3}$ standard to the new 70 ppbv $8 \mathrm{~h}$ average will result in health benefits of USD 6.4 13 billion $\mathrm{yr}^{-1}$ (EPA, 2014). $\mathrm{O}_{3}$ also damages plants, reducing agricultural yields (Tai et al., 2014). Using crop yields and ambient $\mathrm{O}_{3}$ concentrations for 2000, Avnery et al. (2011) estimate the loss of USD 11-18 billion $\mathrm{yr}^{-1}$ worldwide as a result of the reduction of staple crops worldwide (soybean, maize, and wheat) from $\mathrm{O}_{3}$ damage. During summer months, the northern Front Range metropolitan area (NFRMA) of Colorado consistently violated the pre-2016 US EPA National Ambient Air Quality Standard (NAAQS) of $75 \mathrm{ppbv}$ fourth-highest daily maximum $8 \mathrm{~h}$ average (MDA8) ambient $\mathrm{O}_{3}$ concentration, despite proposed reductions in anthropogenic emissions (CDPHE, 2014). The NFRMA has been an $\mathrm{O}_{3}$ non-attainment zone since 2008 (CDPHE, 2009), prompting the Colorado Air Pollution Control Division and the Regional Air Quality Council to develop the Colorado Ozone Action Plan in 2008 to target key $\mathrm{O}_{3}$ precursors: volatile organic compounds (VOCs) and $\mathrm{NO}_{x}\left(\mathrm{NO}+\mathrm{NO}_{2}\right)$ (CDPHE, 2008). Despite these control efforts, 2013 was the 
NFRMA's fourth year in a row to exceed the federal $\mathrm{O}_{3}$ standard (CDPHE, 2016), and the eight NFRMA non-attainment counties, with their combined population $>3.5$ million, exceeded the MDA8 75 ppbv $\mathrm{O}_{3}$ standard on 9-48 days between 2010 and 2012 (AMA, 2015). However, Colorado must comply with the new 70 ppbv MDA8 standard by 2018 . In order to accurately design and implement $\mathrm{O}_{3}$ reduction schemes, a thorough understanding of local $\mathrm{O}_{3}$ trends and chemistry is required.

Ground-level or boundary layer $\mathrm{O}_{3}$ depends on local production, transport, and meteorological parameters:

$$
\frac{\partial\left[\mathrm{O}_{3}\right]}{\partial t}=P\left(\mathrm{O}_{3}\right)+\frac{w_{\mathrm{e}} \mathrm{O}_{3}-u_{\mathrm{d}}\left[\mathrm{O}_{3}\right]}{H}-\nabla \times\left(v\left[\mathrm{O}_{3}\right]\right),
$$

where $\partial\left[\mathrm{O}_{3}\right] / \partial t$ represents the time rate of change of $\mathrm{O}_{3}$ concentration, $P\left(\mathrm{O}_{3}\right)$ is the instantaneous net photochemical $\mathrm{O}_{3}$ production rate (production-loss), $w_{\mathrm{e}} \mathrm{O}_{3}-u_{\mathrm{d}}\left[\mathrm{O}_{3}\right] / H$ represents the entrainment rate $\left(w_{\mathrm{e}}\right)$ of $\mathrm{O}_{3}$ in and deposition rate $\left(u_{\mathrm{d}}\right)$ of $\mathrm{O}_{3}$ out of the mixing layer height $(H)$, and $\nabla \times\left(v\left[\mathrm{O}_{3}\right]\right)$ describes the advection of $\mathrm{O}_{3}$ mixing layer height. Briefly, ground-level $\mathrm{O}_{3}$ is driven by a catalytic chain that is initiated by $\mathrm{RO}_{2}$ production from VOC oxidation (Reaction $\mathrm{R} 1$ ) and propagated by local $\mathrm{NO}_{x}$ emissions (Reactions R2, R3).

$$
\mathrm{RH}+\mathrm{OH}+\mathrm{O}_{2} \rightarrow \mathrm{RO}_{2}+\mathrm{H}_{2} \mathrm{O}
$$

Chain propagation occurs through reactions between $\mathrm{HO}_{2}$ or $\mathrm{RO}_{2}$ radicals with $\mathrm{NO}$ to form $\mathrm{NO}_{2}$ (Reactions $\mathrm{R} 2 \mathrm{a}, \mathrm{b}, \mathrm{R} 3$ ), which is photolyzed (Reaction $\mathrm{R} 4$ ) and leads to net $\mathrm{O}_{3}$ formation (Reaction R5). Reactions between $\mathrm{NO}$ and $\mathrm{O}_{3}$ also produce $\mathrm{NO}_{2}$ (Reaction $\mathrm{R} 6$ ), leading to a null cycle with no net $\mathrm{O}_{3}$ production. Alkoxy (RO) radicals form carbonylcontaining compounds and $\mathrm{HO}_{2}$ (Reaction R7).

$$
\begin{aligned}
& \mathrm{RO}_{2}+\mathrm{NO} \rightarrow \mathrm{RO}+\mathrm{NO}_{2} \\
& \mathrm{RO}_{2}+\mathrm{NO} \rightarrow \mathrm{RONO}_{2} \\
& \mathrm{HO}_{2}+\mathrm{NO} \rightarrow \mathrm{NO}_{2}+\mathrm{OH} \\
& \mathrm{NO}_{2}+h v \rightarrow \mathrm{NO}+\mathrm{O}\left({ }^{3} \mathrm{P}\right) \\
& \mathrm{O}\left({ }^{3} \mathrm{P}\right)+\mathrm{O}_{2} \rightarrow \mathrm{O}_{3} \\
& \mathrm{NO}+\mathrm{O}_{3} \rightarrow \mathrm{NO}_{2}+\mathrm{O}_{2} \\
& \mathrm{RO}+\mathrm{O}_{2} \rightarrow \mathrm{R}^{\prime} \mathrm{CHO}+\mathrm{HO}_{2}
\end{aligned}
$$

For every VOC that enters the cycle, approximately two $\mathrm{NO}_{2}$ radicals are produced - but the resulting carbonylcontaining compounds and organic nitrates can be repeatedly oxidized or photolyzed, further propagating the $P\left(\mathrm{O}_{3}\right)$ chain. Chain termination occurs through $\mathrm{RO}_{2}$ and $\mathrm{HO}_{2}$ selfreactions to form peroxides (dominant termination reactions in the "NO${ }_{x}$-limited regime"), $\mathrm{OH}$ and $\mathrm{NO}_{2}$ reactions to form $\mathrm{HNO}_{3}$ ("NO${ }_{x}$-saturated" or "VOC-limited" regime), or $\mathrm{RO}_{2}$ and $\mathrm{NO}_{x}$ reactions to form organic nitrates $\left(\mathrm{RONO}_{2}\right)$ or peroxyacyl nitrates $\left(\mathrm{RC}(\mathrm{O}) \mathrm{O}_{2} \mathrm{NO}_{2}\right)$. Formation of organic and peroxyacyl nitrates suppresses $P\left(\mathrm{O}_{3}\right)$ but does not shift the crossover point between $\mathrm{NO}_{x}$-limited and $\mathrm{NO}_{x}$-saturated $P\left(\mathrm{O}_{3}\right)$ regimes (Farmer et al., 2011). This crossover point of maximum, or peak, $\mathrm{O}_{3}$ production is controlled by the chain termination reactions and is sensitive to the $\mathrm{HO}_{x}$ production rate and thus VOC reactivity. Decreasing $\mathrm{NO}_{x}$ is an effective $\mathrm{O}_{3}$ control strategy in a $\mathrm{NO}_{x}$-limited system but will increase $\mathrm{O}_{3}$ in a $\mathrm{NO}_{x}$-saturated system. Controls for $\mathrm{NO}_{x}$-saturated systems often focus on reducing anthropogenic VOC reactivity and/or suppressing $\mathrm{NO}_{x}$ emissions sufficiently that the system becomes $\mathrm{NO}_{x}$-limited.

Trends in $\mathrm{O}_{3}$ for 2000-2015 varied across the United States (EPA, 2016a). Using the annual fourth maximum of daily $8 \mathrm{~h}$ averages (MDA- 8 ), the EPA reported a $17 \%$ decrease in the aggregated national average $\mathrm{O}_{3}$. However, regional trends deviated substantially from the national average. For example, the EPA reported a $25 \%$ decrease in $\mathrm{O}_{3}$ throughout the southeast, while the northeast showed a $16 \%$ decrease. Smaller decreases in $\mathrm{O}_{3}$ occurred in the northern Rockies (1\%), in the southwest $(10 \%)$, and on the west coast (4-10\%). These $\mathrm{O}_{3}$ reductions are concurrent with national reductions in $\mathrm{O}_{3}$ precursors of $54 \%$ for $\mathrm{NO}_{x}, 21 \%$ for VOCs, and $50 \%$ for CO (EPA, 2016b). Due to the nonlinear behavior of $\mathrm{O}_{3}$ chemistry described above, reductions in $\mathrm{O}_{3}$ precursors do not necessarily result in reductions of ambient $\mathrm{O}_{3}$. Cooper et al. (2012) reported that 83, 66, and $20 \%$ of rural eastern US sites exhibited statistically significant decreases in summer $\mathrm{O}_{3}$ at the 95th, 50th, and 5th percentiles (1990-2010). No increases in $\mathrm{O}_{3}$ occurred at any sites, indicating that local emission reductions have been effective in those regions. In contrast, $\mathrm{O}_{3}$ in the western US followed a very different trend: only $8 \%$ of western US sites exhibited decreased $\mathrm{O}_{3}$ at the 50th percentile; the 5th percentiles for $\mathrm{O}_{3}$ at $33 \%$ of the sites actually increased. These increases were larger for the lower percentiles, indicating that, while local emissions reductions may have been effective at some sites, increased background $\mathrm{O}_{3}$ offset the improvement.

Lefohn et al. (2010) found that, when comparing $\mathrm{O}_{3}$ at the same sites for a longer period of 1980-2008 and shorter period of 1994-2008, the predominant pattern was a change from a negative trend (decreasing $\mathrm{O}_{3}$ ) during the longer period to no trend (stagnant $\mathrm{O}_{3}$ ) in the shorter period, indicating that $\mathrm{O}_{3}$ reductions had leveled off by the late 2000s. The leveling-off could be a result of either slowed precursor emissions reductions, which is contrary to the EPA estimates, or, more likely, shifting $\mathrm{O}_{3}$ chemistry regimes as precursor emissions are changing. McDonald et al. (2013) report decreased VOC, $\mathrm{CO}$, and $\mathrm{NO}_{x}$ automobile emissions in major US urban centers and decreasing $\mathrm{VOC} / \mathrm{NO}_{x}$ trends from 1990 to 2007 
with a turnaround and small increase after 2007. This will affect local $\mathrm{O}_{3}$ chemistry within the city and at downwind receptor sites. Lefohn et al. (2010) reported that the distributions of high and low hourly $\mathrm{O}_{3}$ values narrowed toward midlevel values in the 12 cities studied, consistent with a reduction in domestic $\mathrm{O}_{3}$ precursors and possibly increased transport of $\mathrm{O}_{3}$ precursors from east Asia. Modeling and measurement studies have also reported increased baseline $\mathrm{O}_{3}$ in the western US due to the transport of $\mathrm{O}_{3}$ precursors from east Asia (Cooper et al., 2010; Parrish et al., 2004; Pfister et al., 2011; Weiss-Penzias et al., 2006). These studies questioned the effectiveness of local precursor emission reductions in controlling local $\mathrm{O}_{3}$ in impacted regions.

The intermountain west is an intriguing environment with potentially increasing background $\mathrm{O}_{3}$ (Cooper et al., 2012). The NFRMA is of particular interest due to the challenge in effective $\mathrm{O}_{3}$ regulation, its growing population, and the dominantly anthropogenic sources of $\mathrm{O}_{3}$ precursors. VOCs have been well studied in the region, with a particular focus on the Boulder Atmospheric Observatory (BAO) in Erie, CO (e.g., Gilman et al., 2013; McDuffie et al., 2016; Pétron et al., 2012; Swarthout et al., 2013; Thompson et al., 2014). VOC composition in the NFRMA was heavily influenced by oil and natural gas (ONG) sources, as well as traffic. In winter $2011, \sim 50 \%$ of VOC reactivity was attributed to ONGrelated VOCs, and $\sim 10 \%$ to traffic (Gilman et al., 2013; Swarthout et al., 2013). Recent studies have shown that ONG and traffic contributed up to 66 and $13 \%$ of the VOC reactivity, respectively, at BAO in mornings for both spring and summer 2015 but that biogenic isoprene was a large, temperature-dependent component of VOC reactivity in the summer, contributing up to $49 \%$ of calculated daytime VOC reactivity (Abeleira et al., 2017). We note that the anthropogenic VOCs were typically lower in 2015 than previous measurements, pointing to the complex roles of meteorology, transport, and local emissions. In contrast, observed isoprene in summer 2012 was much lower than summer 2015, likely due to shifting drought conditions. While temperatures across the two summers were similar, 2012 was a widespread drought year in the region, and 2015 was not. Drought is typically associated with suppressed biogenic VOC emissions (Brilli et al., 2007; Fortunati et al., 2008; Guenther, 2006). Local anthropogenic and biogenic sources are not the only VOC sources in the region: longer-lived VOCs consistent with transport have also been observed (21-44\% of afternoon reactivity in 2015), and smoke from both local and long-distance wildfires impacted air quality in the NFRMA in punctuated events. This smoke was sometimes, but not always, associated with elevated $\mathrm{O}_{3}$ (Lindaas et al., 2017).

The impact of a changing climate on air quality is poorly understood due to the complex climate-chemistry interactions and numerous feedbacks (Jacob and Winner, 2009; Palut and Canziani, 2007). However, increasing temperature is expected to increase $\mathrm{O}_{3}$ (Bloomer et al., 2009; Jacob and Winner, 2009; Palut and Canziani, 2007). The $\mathrm{O}_{3}-$ temperature relationship is attributed to (1) temperaturedependent biogenic VOC emissions that provide a source of VOCs for $\mathrm{OH}$ oxidation leading to increased $\mathrm{HO}_{x}$ cycling (Guenther, 2006; Guenther et al., 1996), (2) thermal decomposition of peroxyacetyl nitrate (PAN) to $\mathrm{HO}_{x}$ and $\mathrm{NO}_{x}$ (Fischer et al., 2014; Singh and Hanst, 1981), and (3) increased likelihood of favorable meteorological conditions for ozone formation (i.e., high insolation, stagnation, circulating wind patterns) (Reddy and Pfister, 2016; Thompson et al., 2001). In addition, increased temperatures and changing soil moisture could alter soil emissions of $\mathrm{NO}_{x}$. Due to the nonlinearity of $P\left(\mathrm{O}_{3}\right)$ chemistry as a function of $\mathrm{NO}_{x}$, the increased VOC and $\mathrm{NO}_{x}$ emissions associated with warming can either increase or decrease $P\left(\mathrm{O}_{3}\right)$ depending on local $\mathrm{NO}_{x}$ levels (i.e., $\mathrm{NO}_{x}$-limited vs. $\mathrm{NO}_{x}$-saturated). Interactions between climate change and regional-scale meteorology are complex and may also impact $\mathrm{O}_{3}$. High and low $\mathrm{O}_{3}$ in the US is coupled to a variety of meteorological parameters, including planetary boundary layer (PBL) heights (White et al., 2007; Reddy and Pfister, 2016), surface temperatures (Bloomer et al., 2009), stratospheric intrusions (Lin et al., 2015), soil moisture, and regional winds (Davis et al., 2011; Thompson et al., 2001). PBL height is coupled to increased temperatures, reduced cloud cover, stronger insolation, and lighter circulating wind patterns, with higher $500 \mathrm{hPa}$ heights correlating to higher average July $\mathrm{O}_{3}$ in the NFRMA (Reddy and Pfister, 2016).

In this paper, we used temperature, $\mathrm{O}_{3}$, and $\mathrm{NO}_{2}$ data from 2000 to 2015 at multiple sites in the NFRMA to investigate why $\mathrm{O}_{3}$ has not decreased in the region despite decreases in $\mathrm{NO}_{x}$. We used a weekend-weekday analysis to elucidate the $\mathrm{NO}_{x}$ regime for $P\left(\mathrm{O}_{3}\right)$ in Denver and explored the temperature dependence of $\mathrm{O}_{3}$ and the role of drought in influencing that relationship in the NFRMA.

\section{Methods}

\subsection{Measurement sites}

We used publicly available $\mathrm{O}_{3}, \mathrm{NO}_{2}$, and temperature data (https://aqs.epa.gov/aqsweb/documents/data_mart_ welcome.html) from eight sites in the NFRMA (Fig. 1, Table 1). The CAMP site is $1.6 \mathrm{~km}$ east of the I-25 interstate highway in downtown Denver. $\mathrm{O}_{3}$ data were available for 2005-2007 and 2012-2015, while $\mathrm{NO}_{2}$ data were available for 2001-2007 and 2010-2015. Welby is roughly $13 \mathrm{~km}$ northeast from the CAMP site, is adjacent to a large lake, and is less than $1.6 \mathrm{~km}$ west of the Rocky Mountain Arsenal open space. $\mathrm{O}_{3}$ data were available for 2000-2009 and 2011-2015, while $\mathrm{NO}_{2}$ data were available for 2001-2002, 2004-2005, 2007-2008, and 2010-2015. The Carriage site is $<1.6 \mathrm{~km}$ west of the I-25 interstate at the same latitude as the CAMP site. $\mathrm{O}_{3}$ data were available for 2000-2012 for the Carriage site. The Fort Collins site is adjacent to Colorado State Uni- 
Table 1. Summary of measurement sites used in this analysis. Note that $\mathrm{NO}_{2}^{*}$ refers to the $\mathrm{NO}_{2}$ detected by the EPA Federal Reference Method and thus includes a fraction of $\mathrm{NO}_{y}$ species.

\begin{tabular}{lrrrl}
\hline Site & Latitude & Longitude & Elevation $(\mathrm{m})$ & Measurements \\
\hline CAMP & 39.7512 & -104.988 & 1591 & $\mathrm{O}_{3} \& \mathrm{NO}_{2}^{*}$ \\
Welby & 39.8382 & -104.955 & 1554 & $\mathrm{O}_{3} \& \mathrm{NO}_{2}^{*}$ \\
Carriage & 39.7518 & -105.031 & 1619 & $\mathrm{O}_{3}$ \\
Fort Collins & 40.5775 & -105.079 & 1523 & $\mathrm{O}_{3}$ \\
Greeley & 40.3864 & -104.737 & 1476 & $\mathrm{O}_{3}$ \\
Rocky Flats & 39.9128 & -105.189 & 1784 & $\mathrm{O}_{3}$ \\
I-25 & 39.7321 & -105.015 & 1586 & $\mathrm{NO}_{2}^{*}$ \\
La Casa & 39.7795 & -105.005 & 1601 & $\mathrm{O}_{3} \& \mathrm{NO}_{2}^{*}$ \\
\hline
\end{tabular}

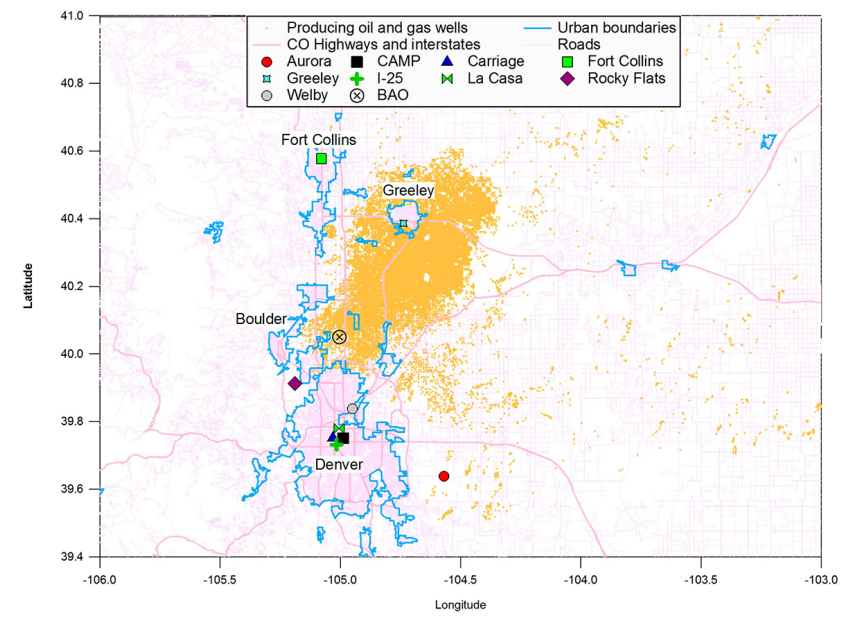

Figure 1. Site map for $\mathrm{O}_{3}$ and $\mathrm{NO}_{2}$ measurements in the NFRMA identified by shapes and colors. Producing oil and gas wells as of 2012 are identified on the map with gold dots. Urban areas are outlined with thick light-blue lines. Major interstates and state highways are identified by thick pink lines.

versity near downtown Fort Collins. $\mathrm{O}_{3}$ data were available for 2000-2015. The Greeley site was located on the southeast side of Greeley and $<1.6 \mathrm{~km}$ south of CO state highway 34 . $\mathrm{O}_{3}$ data were available for 2002-2015. The Rocky Flats site is in a rural area adjacent to the Rocky Flats Wildlife Refuge $<24 \mathrm{~km}$ south of Boulder. The I-25 site is adjacent to the I25 interstate $3.2 \mathrm{~km}$ south of the Carriage and CAMP sites, and it likely intercepts fresh $\mathrm{NO}_{x}$ emissions directly from the I-25 interstate. $\mathrm{NO}_{2}$ data were available for 2015 , but $\mathrm{O}_{3}$ data were not. The La Casa site is $<1.6 \mathrm{~km}$ west of the I-70 and $\mathrm{I}-25$ interstate junction. $\mathrm{O}_{3}$ and $\mathrm{NO}_{2}$ data were available for 2015. Temperature data were available for all sites for all years.

\subsection{Ozone and $\mathrm{NO}_{2}$ data treatment}

Ambient $\mathrm{NO}_{2}$ concentrations were measured by chemiluminescence monitors equipped with molybdenum oxide converters. These monitors are used as the EPA Federal Ref- erence Method for monitoring ambient $\mathrm{NO}_{2}$ concentrations and have a known interference from nitric acid and organic nitrates (Dunlea et al., 2007). The true ambient $\mathrm{NO}_{2}$ mixing ratio is a component of the reported values. $\mathrm{NO}_{2}^{*}$ will be used in this manuscript to refer to the EPA $\mathrm{NO}_{2}$ measurements, which includes the interference and can be considered to be a proxy for total reactive nitrogen oxides $\left(\mathrm{NO}_{y}\right)$. While the absolute $\mathrm{NO}_{2}^{*}$ concentration will be greater than $\mathrm{NO}_{2}$ but less than $\mathrm{NO}_{y}$, trends in $\mathrm{NO}_{2}^{*}$ provided insight on trends in local $\mathrm{NO}_{x}$ emissions. The $\mathrm{O}_{3}$ and $\mathrm{NO}_{2}^{*}$ mixing ratios are filtered to summer months (1 June-31 August) and averaged to a daytime value (10:00-16:00 local time). A site was excluded for a given year when $<50 \%$ of data are available for that summer.

\subsection{Trend analysis}

Following the analyses of Cooper et al. (2012), the statistical significance of the linear trends was tested with a standard $F$-test with the null hypothesis that there is no linear trend $\left(R^{2}=0\right)$. The null hypothesis was rejected with a confidence level $\geq 95 \%$ when the probability $(p)$ associated with the $F$ statistics was low $(p \leq 0.05)$.

\section{Results and discussion}

\subsection{Long-term trends in $\mathrm{O}_{3}$ and $\mathrm{NO}_{2}^{*}$ in the northern Front Range metropolitan area}

Contrary to most other places in the US, $\mathrm{O}_{3}$ in the NFRMA was either stagnant or increasing between 2000 and 2015, despite substantial decreases in $\mathrm{NO}_{x}$ emissions. At most sites in the eastern US and some on the west coast, $\mathrm{O}_{3}$ was decreasing at all percentiles. In the NFRMA, however, five out of six monitoring sites exhibited no change or increasing $\mathrm{O}_{3}$ at the 50th and 95th percentiles in the 2000-2015 period (Fig. 2). The 5 th percentile is often taken as background $\mathrm{O}_{3}$, and studies have shown that background $\mathrm{O}_{3}$ in the western US has increased (Cooper et al., 2010; Parrish et al., 2004; Pfister et al., 2011; Weiss-Penzias et al., 2006). However, only 


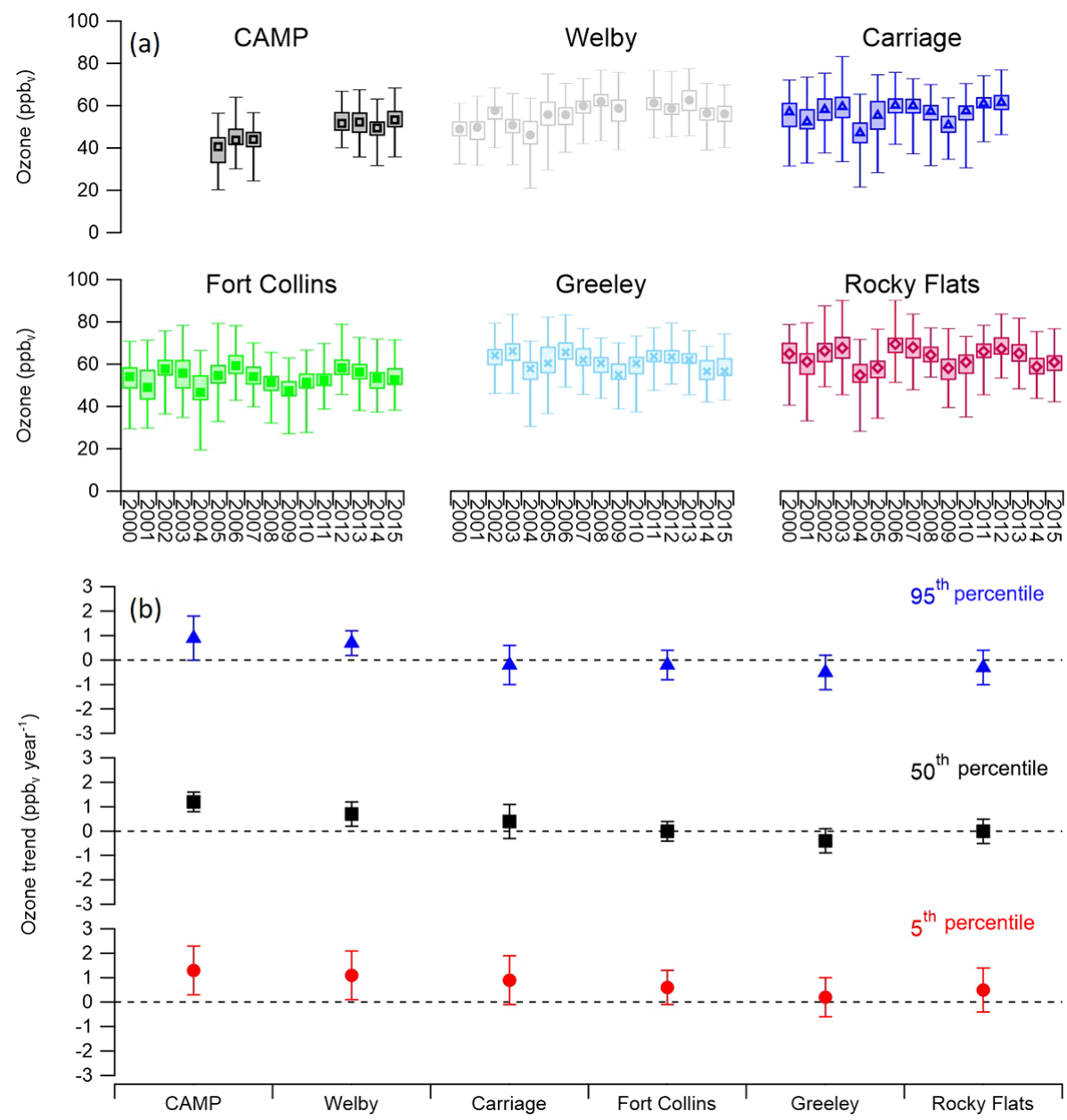

Figure 2. (a) Trends in summer (1 June-31 August) daytime (10:00-16:00 LT) $\mathrm{O}_{3}$ for six sites in the NFRMA between 2000 and 2015. Whiskers correspond to the 5th and 9th percentiles, box thresholds correspond to the 33rd and 67th percentiles, and the marker corresponds to the 50th percentile. Percentiles were calculated from daily daytime averages of hourly $\mathrm{O}_{3}$ measurements at each site. The number of days used for each year's statistics depended on available data $(n=64-92)$. (b) $\mathrm{O}_{3}$ temporal trends were determined as the slope from annual trends (ppbv $\mathrm{O}_{3} \mathrm{yr}^{-1}$ ) from simple one-sided linear regression for the six NFRMA sites for the 95th (blue triangles), 50th (black squares), and 5th (red circles) percentiles. Error bars represent the $95 \%$ confidence interval around the ozone/year linear regression slope.

the CAMP and Welby sites in Denver exhibit significant increasing $\mathrm{O}_{3}$ with trends of $1.3 \pm 1.0$ and $1.1 \pm 1.0 \mathrm{ppbv} \mathrm{yr}^{-1}$, respectively, at the 5 th percentile, with significance determined by passing an $F$-test (Sect. 2.2). The CAMP and Welby sites also exhibit statistically significant increases at the 50th (CAMP: $1.2 \pm 0.4$; Welby: $0.7 \pm 0.5 \mathrm{ppbv} \mathrm{yr}^{-1}$ ) and 95th (CAMP: $1.0 \pm 0.9$; Welby: $0.7 \pm 0.5 \mathrm{ppbv} \mathrm{yr}^{-1}$ ) percentiles. Cooper et al. (2012) reported that the Welby site exhibited no statistically significant increase in $\mathrm{O}_{3}$ from 1990 to 2010 , contrary to what we found for 2000-2015 at the 95th percentile, which could be a result of changing VOC and $\mathrm{NO}_{2}^{*}$ emissions in the 2010-2015 period.

The increasing $\mathrm{O}_{3}$ trends in the NFRMA occurred despite reductions in $\mathrm{NO}_{x} . \mathrm{NO}_{2}^{*}$ at the CAMP site decreased significantly from 2000 at a rate of $-1.0 \pm 0.6$ and $-1.4 \pm 0.6 \mathrm{ppbv} \mathrm{yr}^{-1}$ for the 50th and 95th percentiles, re- spectively, for CAMP (Fig. 3). Welby exhibited a nonsignificant decreasing $\mathrm{NO}_{2}^{*}$ trend at the 95th percentile of $-0.7 \pm 0.8 \mathrm{ppbv} \mathrm{yr}^{-1}$ (Fig. 3). The increased $\mathrm{O}_{3}$ may be due to increased summer temperatures in Colorado, increased regional baseline $\mathrm{O}_{3}$, or increased local $P\left(\mathrm{O}_{3}\right)$ from unknown emission sources (Cooper et al., 2012). VOC emissions steadily increased in Colorado from 2000 to 2012 per the EPA state average annual emissions trend (Fig. 4). To the best of our knowledge, the NFRMA does not have any long-term VOC datasets, but the EPA state average annual emissions trend for Colorado provided an estimate for yearly anthropogenic VOC (AVOC) emissions (EPA, 2016b). All categories of AVOC emissions decreased slightly from 2000 to 2015, except for petroleum-related VOCs, which increased from $7.4 \times 10^{3}$ tons in 2000 to $2.6 \times 10^{5}$ tons in 2011 with a decrease to $1.5 \times 10^{5}$ tons in 2015 (Fig. 4). The US Energy 

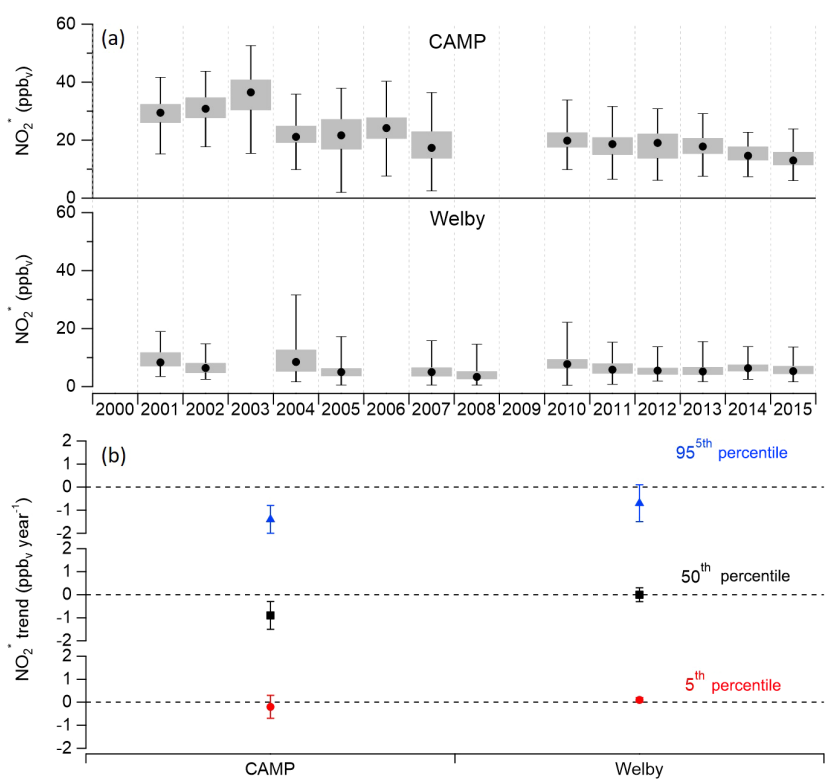

Figure 3. (a) Trends in summer (1 June-31 August) daytime (10:00-16:00 LT) $\mathrm{NO}_{2}^{*}$ for the CAMP and Welby sites in Denver for all available data from 2000 to 2015 . Whiskers correspond to 5th and 95th percentiles, box thresholds correspond to 33rd and 67 th percentiles, and the black marker corresponds to the 50th percentile. (b) $\mathrm{NO}_{2}^{*}$ temporal trends were determined as the slope from annual trends ( $\mathrm{ppbv} \mathrm{NO}_{2} \mathrm{yr}^{-1}$ ) from simple one-sided linear regression for the six NFRMA sites for the 95th (blue triangles), 50th (black squares), and 5th (red circles) percentiles. Error bars represent the $95 \%$ confidence interval around the $\mathrm{NO}_{2}^{*} \mathrm{yr}^{-1}$ linear regression slope.

Information Administration (EIA) reports a twofold increase in active $\mathrm{ONG}$ wells from $\sim 25000$ to $\sim 40000$ from 2010 to 2012 (Fig. 4c) (US-EIA, 2017). However, we note the state average annual emissions are only an estimate and do not include biogenic sources of VOCs, which can contribute substantially to VOC reactivity in the region but vary substantially from year to year (Abeleira et al., 2017). The increased $\mathrm{O}_{3}$ is thus unsurprising for the 2000-2015 time frame. The long-term reduction in $\mathrm{NO}_{x}$ with increasing VOC emissions concurrent with an increase in $\mathrm{O}_{3}$ at both sites suggests that the downtown Denver sites were in a $\mathrm{NO}_{x}$-saturated $P\left(\mathrm{O}_{3}\right)$ regime and that, as $\mathrm{NO}_{2}^{*}$ decreased and VOC reactivity increased, $P\left(\mathrm{O}_{3}\right)$ was increasing towards peak production.

\subsection{Weekend-weekday effect in Denver, CO}

The "weekend-weekday effect" describes how anthropogenic emissions of $\mathrm{O}_{3}$ precursors can be statistically different on weekdays versus weekends, resulting in different secondary chemistry. This effect can be used to elucidate information about local chemical regimes (i.e., CARB, 2003; Murphy et al., 2007; Fujita et al., 2003; Warneke et al., 2013; Pollack et al., 2012; Cleveland et al., 1974; Heuss et al.,
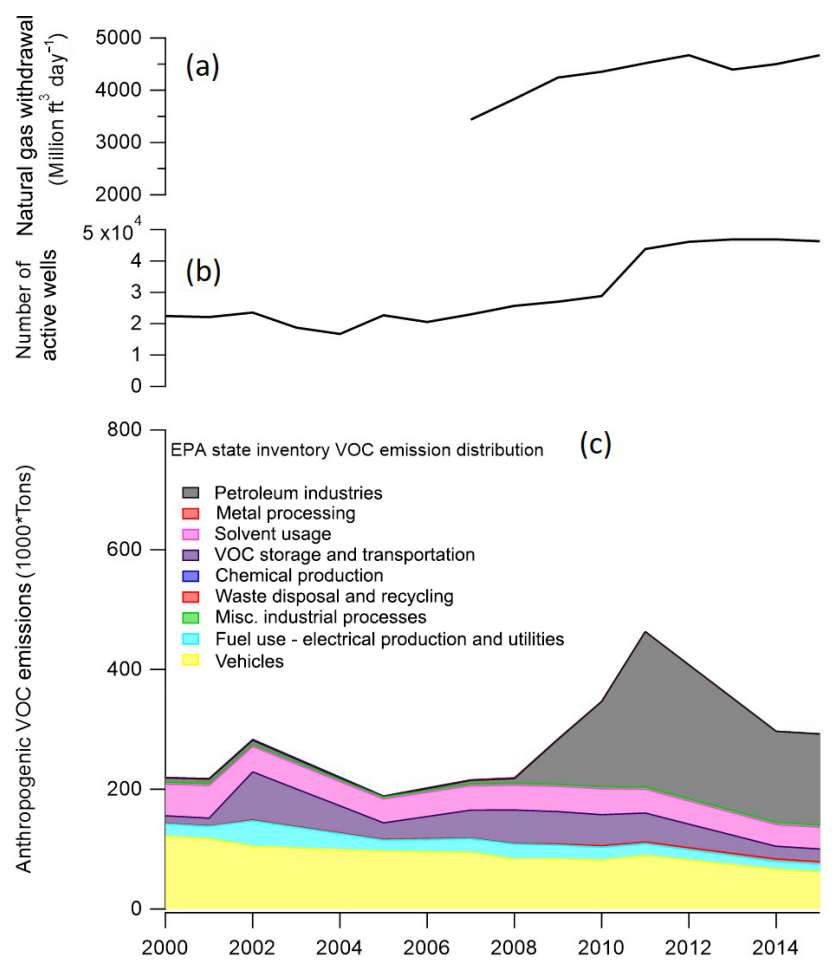

Figure 4. (a) Estimated yearly averaged natural gas withdrawals in Colorado (US-EIA, 2017). (b) Yearly average number of active ONG well operations (US-EIA, 2017). (c) Anthropogenic VOC emission estimates from the EPA state average annual emissions trend for Colorado (EPA, 2016b). Emission sources are separated by color and are added to give the total VOC emission estimates for anthropogenic VOCs. Biogenic VOCs and VOCs from biomass burning (controlled fires and wildfires) are not included.

2003). Traffic patterns in urban regions are different between weekends and weekdays from a decrease in heavy-duty truck traffic on weekends (Marr and Harley, 2002). VOCs are expected to be stable across the week, as major VOC sources do not vary by day of week. Despite this reduction in heavyduty trucking traffic, $\mathrm{O}_{3}$ can be higher on weekends than on weekdays if the system is in a $\mathrm{NO}_{x}$-saturated regime because decreased $\mathrm{NO}_{x}$ increases $P\left(\mathrm{O}_{3}\right)$, while decreased $\mathrm{NO}$ also reduces $\mathrm{O}_{3}$ titration to $\mathrm{NO}_{2}$ (Fujita et al., 2003; Heuss et al., 2003; Marr and Harley, 2002; Murphy et al., 2007; Pollack et al., 2012; Pusede and Cohen, 2012). Thus urban regions, which are often $\mathrm{NO}_{x}$-saturated, tend to follow a dayof-week pattern in both $\mathrm{NO}_{x}$ and $\mathrm{O}_{3}$ (Fujita et al., 2003; Heuss et al., 2003; Pusede and Cohen, 2012), while rural and semi-urban areas often experience no change in $\mathrm{NO}_{x}$ or $\mathrm{O}_{3}$ from weekdays to weekends. Rural regions have a lower population density, less defined daily traffic patterns, and minimal or no commercial trucking (Heuss et al., 2003). The weekend-weekday effect typically relies on the assumption that the VOC reactivity and thus $\mathrm{HO}_{x}$ production are unchanged between the weekend and weekdays. However, this is not always the case, as decreased weekend $\mathrm{NO}_{x}$ re- 


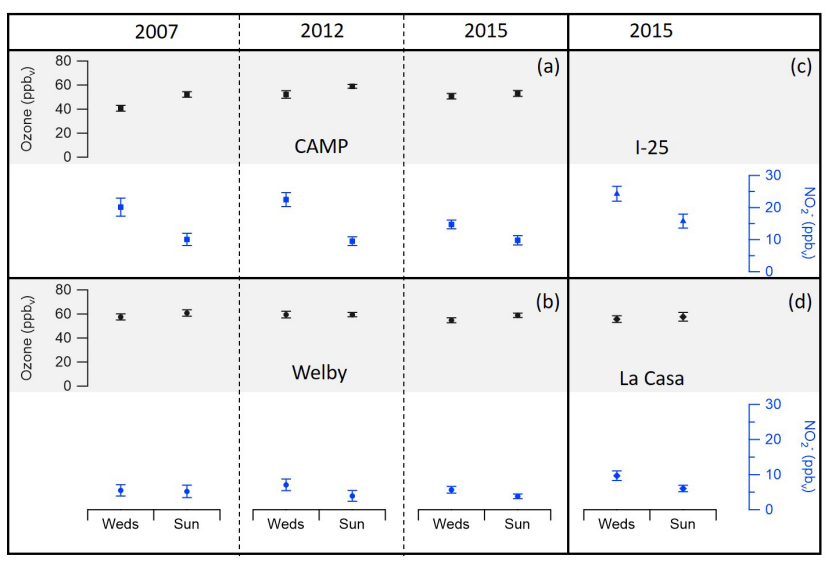

Figure 5. Weekend-weekday analysis (Sunday vs. Wednesday) for $\mathrm{O}_{3}$ (black with shading) and $\mathrm{NO}_{2}^{*}$ (blue) for the CAMP (a, squares), Welby (b, circles), and La Casa (c, diamonds) sites in Denver. I-25 (d, triangles) is limited to $\mathrm{NO}_{2}^{*}$ due to data availability. All sites have plots for 2015, but only CAMP (a) and Welby (b) are additionally plotted for 2007 and 2012 due to data availability. Wednesday is representative of weekday $\mathrm{NO}_{2}^{*}$ and typically is not different than the average of Tuesday, Wednesday, and Thursday at a $95 \%$ confidence for this dataset. Monday, Friday, and Saturday are considered carryover or "mixed" days between weekdays and weekends and are ignored. Error bars represent $95 \%$ confidence intervals around the summertime mean of Wednesday or Sunday $\mathrm{O}_{3}$ or $\mathrm{NO}_{2}^{*}$.

duces $\mathrm{NO}_{x}+\mathrm{OH}$ reactions and thereby increases weekend $\mathrm{OH}$ and $\mathrm{O}_{3}$ (Warneke et al., 2013). Few studies of VOCs in the NFRMA exist, but our previous work found no significant difference in measured $\mathrm{VOC}$ reactivity at the BAO site between weekends and weekdays in summer 2015 (Abeleira et al., 2017).

In the NFRMA, long-term (i.e., $10+$ years) $\mathrm{NO}_{2}^{*}$ datasets only existed at the CAMP and Welby sites. Two sites in Denver added $\mathrm{NO}_{2}^{*}$ measurements in 2015: the I-25 and La Casa sites. The CAMP, I-25, and La Casa sites are all located within a $6 \mathrm{~km}$ radius that straddles the I- 25 motorway; are surrounded by a dense network of roads, businesses, and industrial operations; and experience high traffic density. Welby is located roughly $13 \mathrm{~km}$ northeast from the three other sites and borders a large lake and the Rocky Mountain Arsenal open space. Welby is thus more "suburban" than the other sites. Median $\mathrm{NO}_{2}^{*}$ at CAMP decreased from $37 \mathrm{ppbv}$ in 2003 to $13 \mathrm{ppbv}$ in 2015. The median weekday I-25 and La Casa $\mathrm{NO}_{2}^{*}$ mixing ratios in 2015 were similar to CAMP in 2007 (Fig. 5), indicating that, although $\mathrm{NO}_{2}^{*}$ emission reductions have been effective in the region, mixing ratios in Denver are very site specific.

An observable weekend-weekday effect in $\mathrm{NO}_{2}^{*}$ existed for all years at the CAMP site, and most years at the Welby site with intermittent years that do not have a clear difference in weekday and weekend $\mathrm{NO}_{2}^{*}$. $\mathrm{NO}_{2}^{*}$ decreased by 20 $50 \%$ from weekdays to weekends. Assuming that meteorol-

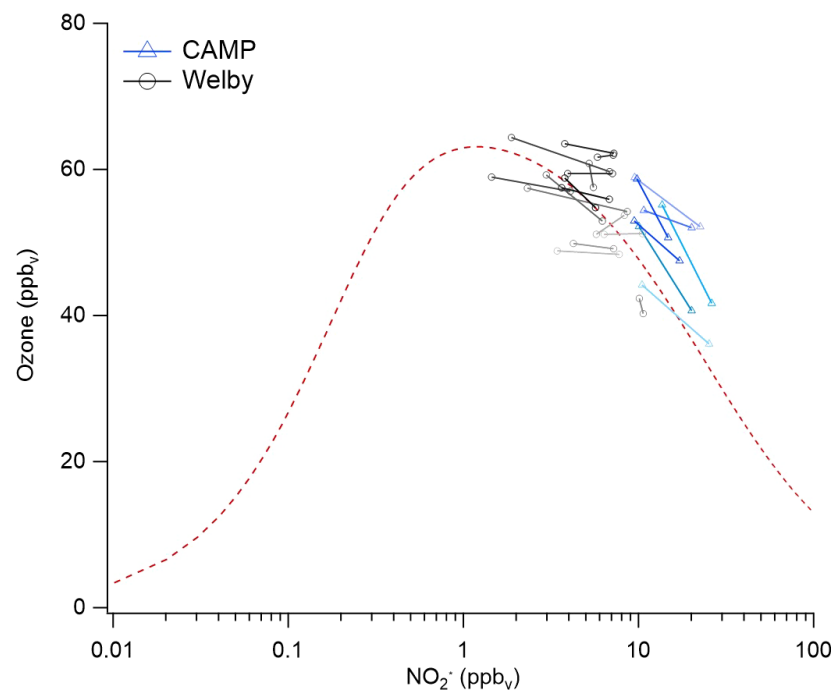

Figure 6. Weekday and weekend $\mathrm{O}_{3}$ versus $\mathrm{NO}_{2}^{*}$ for Welby (black) and CAMP (blue) sites. Tethered symbols correspond to average Wednesday values for weekdays and average Sunday values for weekends for each year depending on data availability. The color shading corresponds to year, with the lightest shade corresponding to the earliest year (2000 for Welby, 2005 for CAMP) and 2015 as the darkest shade. The $95 \%$ confidence intervals for each year are $<5 \mathrm{ppb}_{\mathrm{v}}$ for $\mathrm{O}_{3}$ and $<2.5 \mathrm{ppbv}$ for $\mathrm{NO}_{2}^{*}$. The dashed blue line is a visual aid to guide the reader's eye to the nonlinear $\mathrm{O}_{3}$ curve and was generated from the simple analytic model described by Farmer et al. (2011).

ogy does not systematically change between weekends and weekdays, we consider the weekend-weekday effect in $\mathrm{O}_{3}$ to be indicative of changes in $P\left(\mathrm{O}_{3}\right)$ due to lower $\mathrm{NO}_{x}$. Figure 6 follows the analysis of Pusede and Cohen (2012), presenting summer average weekday and weekend $\mathrm{O}_{3}$ values for Welby and CAMP with the values tethered for each year. The values followed a curve similar to a modeled $P\left(\mathrm{O}_{3}\right)$ curve and indicates that reductions in $\mathrm{NO}_{x}$ emissions from 2000 to 2015 have placed $\mathrm{O}_{3}$ production in the Denver region in a transitional phase from $\mathrm{NO}_{x}$-saturated to peak $P\left(\mathrm{O}_{3}\right)$. This analysis suggests that continued reductions of $\mathrm{NO}_{x}$ would shift the system to a $\mathrm{NO}_{x}$-limited regime, in which changes in VOC reactivity due to shifting anthropogenic or biogenic emissions would have little effect on $\mathrm{O}_{3}$.

The average change in $\mathrm{O}_{3}\left(\Delta \mathrm{O}_{3}\right)$ and $\mathrm{NO}_{2}^{*}\left(\Delta \mathrm{NO}_{2}^{*}\right)$ from weekend to weekday is plotted as a function of year for the six available $\mathrm{O}_{3}$ NFRMA sites and the two $\mathrm{NO}_{2}^{*}$ sites (Fig. $7 \mathrm{a}, \mathrm{b}$ ). A positive $\Delta \mathrm{O}_{3}$ reflects a higher $\mathrm{O}_{3}$ concentration on the weekend than weekdays, consistent with a $\mathrm{NO}_{x}$ saturated system. A negative $\Delta \mathrm{O}_{3}$ is consistent with a $\mathrm{NO}_{x}$ limited system in which $\mathrm{O}_{3}$ decreases when $\mathrm{NO}_{x}$ decreases. The weekend-weekday effect exhibits a non-significant decreasing trend from 2000 to 2015 for yearly averages of the six sites. This is consistent with the decreased regional $\mathrm{NO}_{x}$ emissions, which would move the system from $\mathrm{NO}_{x}$ - 


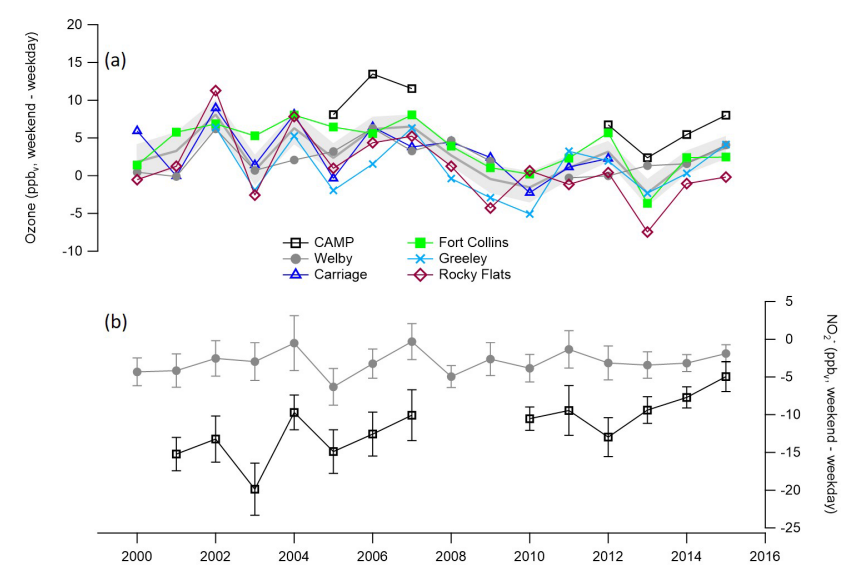

Figure 7. (a) The change in $\mathrm{O}_{3}$ calculated as average weekend (Sunday) minus weekday (Wednesday) $\mathrm{O}_{3}$ for the six NFRMA sites identified by color and marker. The solid grey line is the average of the sites. The inclusion of a site in the averaging for a given year was dependent on available data for that year. The light-grey shading represents \pm the $95 \%$ confidence interval of all Wednesday and Sunday hourly values for each year for sites with available data. (b) The change in $\mathrm{NO}_{2}^{*}$ is calculated identically to $\mathrm{O}_{3}$ in (a) for the CAMP and Welby sites, and the error bars represent the $95 \%$ confidence interval of the averages.

saturated to peak $P\left(\mathrm{O}_{3}\right)$ in the absence of large changes in VOC reactivity. The CAMP site was the exception and consistently had a larger $\Delta \mathrm{O}_{3}$ than the other sites. This was consistent with the CAMP site's higher $\mathrm{NO}_{2}^{*}$ relative to Welby and the $30-50 \%$ decrease in $\mathrm{NO}_{2}^{*}$ from weekdays to the weekend. Measured $\mathrm{NO}_{2}^{*}$ decreased at both CAMP and Welby (Fig. 3b), but with larger decreases at the CAMP site. The $\Delta \mathrm{NO}_{2}^{*}$ at Welby remained stable with an average value of $-1.7 \pm 0.9 \mathrm{ppbv}$, while $\Delta \mathrm{NO}_{2}^{*}$ at the CAMP exhibited a statistically significant decrease of $0.6 \pm 0.4 \Delta \mathrm{NO}_{2}^{*}$ ppbv $\mathrm{yr}^{-1}$. The decreasing $\Delta \mathrm{NO}_{2}^{*}$ at the CAMP site appears to be converging with the $\Delta \mathrm{NO}_{2}^{*}$ at the Welby site. It is unlikely that traffic patterns are assimilating between the two sites, and a more plausible explanation is that emission control technologies on heavy-duty commercial fleet vehicles are reducing the impact on emissions of those specific vehicles and reducing the measurable $\Delta \mathrm{NO}_{2}^{*}$ (Bishop et al., 2015). The $\Delta \mathrm{O}_{3}$ decreased across the NFRMA outside of the most highly trafficked regions in Denver, again consistent with the hypothesis that the NFRMA $P\left(\mathrm{O}_{3}\right)$ regime has transitioned from $\mathrm{NO}_{x}$-saturated chemistry towards peak $P\left(\mathrm{O}_{3}\right)$. Two sites, Greeley and Rocky Flats, show negative $\Delta \mathrm{O}_{3}$ values in recent years, suggesting that those sites have, at least in those specific years, transitioned to $\mathrm{NO}_{x}$-limited chemistry. Collectively, this weekend-weekday analysis suggests that the region is $\mathrm{NO}_{x}$-saturated, but transitioning to a $\mathrm{NO}_{x}$-limited region. Increases in $\mathrm{O}_{3}$ may thus be due to a combination of decreasing $\mathrm{NO}_{x}$ and increasing VOC emissions. While the lack of long-term VOC measurements prevents identi- fication and quantification of those VOC sources, the state average annual emissions suggested that petroleum-related VOCs have increased. However, we note that large increases in VOC reactivity shift the transition point between $\mathrm{NO}_{x}$ limited and $\mathrm{NO}_{x}$-saturated regions to higher $\mathrm{NO}_{x}$ concentrations. The clear regional decrease in the weekend-weekday effect, as evidenced by the decreasing $\Delta \mathrm{O}_{3}$ trend, indicates that the region is transitioning and that any increases in VOC reactivity have not been so large as to dramatically inhibit this effect.

\subsection{The $\mathrm{O}_{3}$-temperature penalty in the NFRMA}

Increasing temperature can increase $P\left(\mathrm{O}_{3}\right)$ by enhancing biogenic and evaporative VOC emissions but has variable impacts on the weekend-weekday effect as a result of changing $\mathrm{NO}_{x}$ emissions (Pusede et al., 2014). We showed that while $\mathrm{O}_{3}$ increased with temperature in the NFRMA, consistent with a $\mathrm{NO}_{x}$-saturated regime, this relationship was variable year to year. Ambient $\mathrm{O}_{3}$ was correlated with increasing temperature across the US (Bloomer et al., 2009; Jacob and Winner, 2009; Pusede et al., 2014). While one study in the NFRMA from summer 2012 found that biogenic VOCs (i.e., isoprene) had a minor impact on VOC reactivity at the BAO site (McDuffie et al., 2016), Abeleira et al. (2017) found that isoprene contributed up to $47 \%$ of VOC reactivity on average in the late afternoon in summer 2015. Studying the temperature dependence of $\mathrm{O}_{3}$ allows us to investigate the extent to which biogenic VOCs influenced $P\left(\mathrm{O}_{3}\right)$ in the NFRMA and the interannual variability of those temperature-dependent VOC sources, as well as the shift from a $\mathrm{NO}_{x}$-saturated to $\mathrm{NO}_{x}$-limited $P\left(\mathrm{O}_{3}\right)$ regime. $\mathrm{NO}_{x}$-saturated regimes should be sensitive to changes in VOC reactivity, while $\mathrm{NO}_{x}$-limited systems should not. We note that, while anthropogenic VOCs such as solvents may be temperature dependent and contribute to this trend, we only observed temperature trends in isoprene at the BAO site in 2015 - though we acknowledge that the observed VOC suite in that study was limited (Abeleira et al., 2017).

$\mathrm{O}_{3}$ in the NFRMA demonstrated a clear temperature dependence at all percentiles for all sites, but with slopes that vary by site and year (Fig. 8, Fig. 9). The NFRMA appears to be $\mathrm{NO}_{x}$-saturated or near peak $P\left(\mathrm{O}_{3}\right)$ for all years, consistent with temperature-dependent biogenic emissions impacting ambient $\mathrm{O}_{3}$. The variance in the $\mathrm{O}_{3}$-temperature dependence was likely external to meteorological effects. High temperature and linked meteorological parameters - such as high $500 \mathrm{hPa}$ heights, stagnant winds, or circulating wind patterns - do indeed correlate with high- $\mathrm{O}_{3}$ events in Colorado (Reddy and Pfister, 2016), but those parameters should not affect the $\mathrm{O}_{3}$-temperature relationship.

Figure 8a shows daytime summer $\mathrm{O}_{3}$ averaged in nonuniform temperature bins with bin size dictated by maintaining an equal number of data points in each temperature bin for CAMP, Fort Collins, and Rocky Flats for years in 

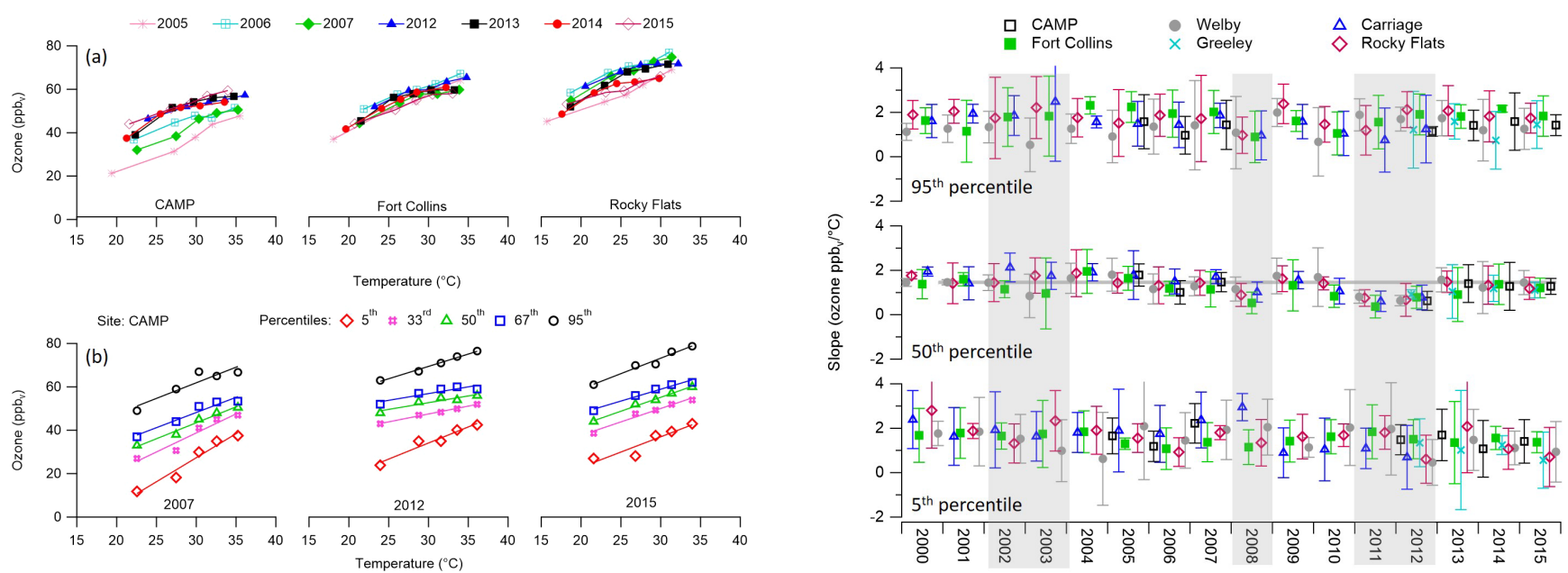

Figure 8. (a) $\mathrm{O}_{3}$ versus temperature for CAMP, Fort Collins, and Rocky Flats. Hourly $\mathrm{O}_{3}$ is binned by hourly temperature, with bins containing 51-110 points for $\mathrm{O}_{3}$ and temperature depending on data availability at a site. The temperature bins typically contained 100110 data points ( $>90 \%$ of temperature bins for all sites in all available years). Average $\mathrm{O}_{3}$ of each bin is plotted versus the average temperature of each bin. Markers and colors represent yearly averages for each site. Error bars were left off for visual clarity, but the $95 \%$ confidence intervals around the yearly bin averages are typically $<8$ ppbv. Years were selected based on availability of overlapping data for multiple sites. (b) One-sided linear regressions of equal point temperature bins for the 5th (red open diamond), 33rd (pink hash), 50th (green open triangle), 67th (blue open square), and 95th (black open circle) percentiles for the CAMP site for 2007 (left), 2012 (middle), and 2015 (right).

which data were available at all sites. For every temperature bin, $\mathrm{O}_{3}$ was higher at Rocky Flats than at Fort Collins, and both were higher than at CAMP. The Rocky Flats site was the most rural of the chosen sites adjacent to the 1600 ha Rocky Flats Wildlife Refuge but was $<24 \mathrm{~km}$ from downtown Boulder. Rocky Flats likely had higher $\mathrm{O}_{3}$ because it was downwind of both $\mathrm{NO}_{x}$ (Boulder, Denver) and VOC sources (forested regions in the neighboring foothills), had fewer nearby fresh $\mathrm{NO}_{x}$ sources and thus less $\mathrm{NO}+\mathrm{O}_{3}$ titration, and experienced enhanced $P\left(\mathrm{O}_{3}\right)$ due to the region being near the crossover point between $\mathrm{NO}_{x}$-saturated and $\mathrm{NO}_{x}$-limited chemical regimes (Fig. 6).

Bloomer et al. (2009) reported average $\mathrm{O}_{3}$-temperature relationships of $2.2-2.4 \mathrm{ppbv}^{\circ} \mathrm{C}^{-1}$ for the northeast, southeast, and Great Lakes regions of the US across all $\mathrm{O}_{3}$ percentiles. In contrast, the southwest region, including Colorado, had an average relationship of $1.4 \mathrm{ppbv}^{\circ} \mathrm{C}^{-1}$ (Bloomer et al., 2009). We find that $\mathrm{O}_{3}$ was indeed correlated with temperature at all NFRMA sites, with relationships that ranged from 0.07 to $1.95 \mathrm{ppbv}^{\circ} \mathrm{C}^{-1}$ with an average of $1.0 \pm 0.4 \mathrm{ppbv}^{\circ} \mathrm{C}^{-1}$ (Fig. 8) for all sites and years. Quantitatively, this temperature dependence was low relative to other US sites, consistent with previous findings that biogenic VOCs contribute to, but

Figure 9. Slopes from one-sided linear regression of $\mathrm{O}_{3}$ versus temperature (i.e., the temperature dependence of $\mathrm{O}_{3}$ ). Hourly $\mathrm{O}_{3}$ (10:00-16:00 LT) is binned by hourly temperature, with bins containing 51-110 points for $\mathrm{O}_{3}$ and temperature depending on data availability at a site. The temperature bins typically contained 100110 data points ( $>90 \%$ of temperature bins for all sites in all available years). The slopes of $\mathrm{O}_{3}$ versus temperature for the 5th, 50th, and 95th percentiles for the $\mathrm{O}_{3}$-temperature bins are shown. Data are shown for CAMP (black squares), Welby (grey solid circles), Carriage (blue open triangles), Fort Collins (green solid squares), Greeley (teal Xs), and Rocky Flats (magenta open diamonds). Shaded years correspond to Colorado summers with moderate to severe drought conditions. Error bars are $\pm 95 \%$ confidence interval of the slopes. Faint grey line across the 50th percentile is the average slope bounded by the $95 \%$ confidence interval for years excluding 2008, 2011, and 2012.

do not dominate, VOC reactivity in the NFRMA (McDuffie et al., 2016; Abeleira et al., 2017). However, the six NFRMA sites exhibited significant variability in the 5th, 50th, and 95th percentiles among the sites both within a given year and across years (Fig. 9). The 5th and 95th $\mathrm{O}_{3}$ percentiles showed greater variability and larger uncertainties in the slopes than the 50th percentile. This indicated that baseline $\mathrm{O}_{3}$ and high$\mathrm{O}_{3}$ events in the region were less dependent on temperature. Baseline $\mathrm{O}_{3}$ was likely tied to the transport of $\mathrm{O}_{3}$ and $\mathrm{O}_{3}$ precursors from the west coast (Cooper et al., 2012), while the high- $\mathrm{O}_{3}$ events were likely tied to a combination of meteorological parameters, including $500 \mathrm{hPa}$ heights and stagnation events (Reddy and Pfister, 2016), stratospheric intrusions (Lin et al., 2015), and local temperature-independent VOC emissions. In contrast, the 50th percentile showed a clear temperature dependence at all sites in most years (Fig. 8, Fig. 9), indicating that mean $\mathrm{O}_{3}$ was typically influenced by local temperature-dependent, and likely biogenic, VOC emissions.

Unlike for ambient $\mathrm{O}_{3}$ and the weekend-to-weekday $\Delta \mathrm{O}_{3}$, we noted no clear long-term trend in the $\mathrm{O}_{3}$-temperature relationship. The $\mathrm{O}_{3}$-temperature relationships showed sim- 
ilar interannual patterns for the six sites at the 50th percentile (Fig. 9). Specifically, years 2008 and 2011-2012 have suppressed $\mathrm{O}_{3}$-temperature slopes for the 50th percentile. Reddy and Pfister (2016) reported high $500 \mathrm{hPa}$ heights and $\mathrm{O}_{3}$ for 2002-2003, 2006, and 2012, while 2004 and 2009 had low $500 \mathrm{hPa}$ heights and low $\mathrm{O}_{3}$, so those exceptional years cannot be explained solely by meteorology. However, those exceptional years (2008 and 2011-2012) did correspond to years in which Colorado was in moderate-severe drought with little soil moisture (NOAA, 2017). Years 2002-2003 also exhibited moderate to severe drought conditions in Colorado, and some but not all sites exhibited suppressed $\mathrm{O}_{3}-$ temperature slopes.

Drought in the NFRMA is connected to changes in mountain-plains circulation and lower surface moisture, which reduces the surface latent heat flux and causes increased surface temperature. These increased surface temperatures lead to strong mountain-plains circulation, stagnant wind conditions, higher PBLs, and $500 \mathrm{hPa}$ heights, all of which are known to correlate with high- $\mathrm{O}_{3}$ episodes (Reddy and Pfister, 2016; Ek and Holtslag, 2004; Zhou and Geerts, 2013). Drought is also connected to reduced isoprene emissions (Brilli et al., 2007; Fortunati et al., 2008; Guenther et al., 2006). Consistent with this concept, Abeleira et al. (2017) noted that isoprene was 2-4 times higher at the Boulder Atmospheric Observatory site in summer 2015 (a non-drought year) than in summer 2012 (a drought year). Such a decrease in biogenic isoprene emissions should also suppress the $\mathrm{O}_{3}-$ temperature dependence in $\mathrm{NO}_{x}$-saturated regimes, a trend that was observed in the NFRMA (Fig. 9).

The suppressed $\mathrm{O}_{3}$-temperature relationship during drought years in the NFRMA demonstrated the importance of temperature-dependent VOCs in driving $P\left(\mathrm{O}_{3}\right)$ in the region, particularly at the mid-range 50th percentile - but not at the baseline 5th percentile. A standard $t$ test showed that the 50th- and 95th-percentile slopes (i.e., temperature dependence of average and high $\mathrm{O}_{3}$ concentrations) are indeed different between the drought and non-drought years at the $95 \%$ confidence limit. If $\mathrm{NO}_{x}$ emissions continue to decrease, and the NFRMA continues its trend towards a $\mathrm{NO}_{x}$ limited regime (Fig. 7), the $\mathrm{O}_{3}$-temperature dependence should also decrease and temperature-dependent VOCs will play a smaller role in driving $\mathrm{O}_{3}$ production. However, this would require substantial decreases in $\mathrm{NO}_{x}$ for the heavytraffic region of Denver to become fully $\mathrm{NO}_{x}$-limited, so temperature-dependent VOCs will likely remain important in at least some regions of the NFRMA.

\section{Conclusions}

$\mathrm{O}_{3}$ decreased across most of the country as anthropogenic $\mathrm{NO}_{x}$ and VOC emissions were reduced, with the exception of background $\mathrm{O}_{3}$ in the west (Cooper et al., 2012). In contrast, five out of six sites in the NFRMA showed no change or increasing $\mathrm{O}_{3}$ at the 50th and 95th percentiles between 2000 and 2015. While $\mathrm{NO}_{x}$ levels have been reduced at the CAMP and Welby sites in Denver, anthropogenic VOC emission estimates have increased as a result of increased petroleum-related activities (Fig. 4). A weekend-weekday analysis demonstrated that most sites in the NFRMA were $\mathrm{NO}_{x}$-saturated but are transitioning to, and in two cases may already have reached, the peak $P\left(\mathrm{O}_{3}\right)$ crossover point between $\mathrm{NO}_{x}$-saturated and $\mathrm{NO}_{x}$-limited regimes. Some of the more rural NFRMA sites may already be in or near a $\mathrm{NO}_{x}$-limited system. This transition suggests that increasing anthropogenic VOC emissions will have less of an effect on $P\left(\mathrm{O}_{3}\right)$ in the region if $\mathrm{NO}_{x}$ reductions continue, though VOCs remain the limiting reagent for ozone production in most of the NFRMA sites in 2015. Thus, the combined factors of increasing anthropogenic VOC emissions and decreasing $\mathrm{NO}_{x}$ in a $\mathrm{NO}_{x}$-saturated system are likely culprits in the increasing $\mathrm{O}_{3}$ trends within the NFRMA over the past 15 years. Although the median $\mathrm{NO}_{2}^{*}$ decreased at the CAMP site from $37 \mathrm{ppbv}$ in 2003 to $13 \mathrm{ppbv}$ in 2015 , the site remains on the steep transitional part of the $P\left(\mathrm{O}_{3}\right)$ curve between $\mathrm{NO}_{x}$-saturated and peak $P\left(\mathrm{O}_{3}\right)$ chemistry (Fig. 6). Continued reductions in $\mathrm{NO}_{x}$ emissions alone could lead to increased $\mathrm{O}_{3}$ in the downtown Denver area until the $P\left(\mathrm{O}_{3}\right)$ chemistry has passed the peak production region, although concurrent reductions in VOCs could mitigate the increase in $P\left(\mathrm{O}_{3}\right)$. As sources of VOCs and $\mathrm{NO}_{x}$ change in the NFRMA with increased population, growth in the oil and gas sector, and changing emissions regulations, continued analysis of $\mathrm{O}_{3}$ and $\mathrm{NO}_{x}$ will be essential for understanding the shifting $P\left(\mathrm{O}_{3}\right)$ regime. However, such analyses would benefit greatly from long-term $\mathrm{NO}_{x}$ measurements at additional sites in the NFRMA.

$\mathrm{O}_{3}$ in the NFRMA exhibits temperature dependence at all sites, but with varying intensities for different years. The 5th and 95th $\mathrm{O}_{3}$ percentiles demonstrated significant variability in temperature dependence for different sites in the same year and across the study period, indicating that high$\mathrm{O}_{3}$ events and background $\mathrm{O}_{3}$ have other important controlling factors such as transport of long-lived $\mathrm{O}_{3}$ precursors from the west or meteorological parameters. Two time periods exhibit a clearly suppressed $\mathrm{O}_{3}$-temperature dependence at the 50th percentile (2008 and 2011-2012), coinciding with moderate to extreme drought conditions in the NFRMA. These observations are consistent with the hypothesis that long-term drought stress reduces biogenic VOC emissions and suppresses the $\mathrm{O}_{3}$-temperature dependency. However, we emphasize that this effect is most clearly observed at the 50th percentile, rather than the 5th or 95th percentiles, suggesting that biogenic VOCs have a greater influence on mean $\mathrm{O}_{3}$ than on background $\mathrm{O}_{3}$ or high- $\mathrm{O}_{3}$ events in the NFRMA. Climate change is predicted to increase temperatures and thus increase $\mathrm{O}_{3}$ by $1-10 \mathrm{ppbv}$ on a national scale (Jacob and Winner, 2009). However, climate change models predict more extreme precipitation events in many ar- 
eas, and estimates for Colorado and the intermountain west suggest that drought may become more common in the region (IPCC, 2014). The work herein suggests that drought can temporarily suppress the $\mathrm{O}_{3}$-temperature penalty in the NFRMA and perhaps other $\mathrm{NO}_{x}$-saturated regions by reducing temperature-dependent biogenic VOC emissions.

Data availability. Ozone, $\mathrm{NO}_{2}$, and temperature data are publicly available data hosted by the Environmental Protection Agency: http: //www.epa.gov/ttn/airs/aqsdatamart (EPA, 2016c).

Data on natural gas withdrawals and the number of wells in Colorado (Fig. 4a, b) are publicly available from the US Energy Information Administration: www.EIA.gov.

The annual VOC emission distributions (Fig. 4c) data are publicly available from the US Environmental Protection Agency: https://www.epa.gov/air-emissions-inventories/ air-pollutant-emissions-trends-data (EPA, 2016b).

Competing interests. The authors declare that they have no conflict of interest.

Acknowledgements. We thank the National Oceanic and Atmospheric Administration for funding this work (award no. NA14OAR4310148).

Edited by: R. Harley

Reviewed by: two anonymous referees

\section{References}

Abeleira, A., Pollack, I., Sive, B. C., Zhou, Y., Fischer, E. V., and Farmer, D.: Source Characterization of Volatile Organic Compounds in the Colorado Northern Front Range Metropolitan Area during Spring and Summer 2015, J. Geophys. Res.-Atmos., 122, 3595-3613, 2017.

AMA: State of the Air 2015, edited by: Association, A. L., Chicago, IL, 2015.

Avnery, S., Mauzerall, D. L., Liu, J., and Horowitz, L. W.: Global crop yield reductions due to surface ozone exposure: 1. Year 2000 crop production losses and economic damage, Atmos. Environ., 45, 2284-2296, 2011.

Bishop, G. A., Hottor-Raguindin, R., Stedman, D. H., McClintock, P., Theobald, E., Johnson, J. D., Lee, D.-W., Zietsman, J., and Misra, C.: On-road Heavy-duty Vehicle Emissions Monitoring System, Environ. Sci. Technol., 49, 16391645, https://doi.org/10.1021/es505534e, 2015.

Bloomer, B. J., Stehr, J. W., Piety, C. A., Salawitch, R. J., and Dickerson, R. R.: Observed relationships of ozone air pollution with temperature and emissions, Geophys. Res. Lett., 36, https://doi.org/10.1029/2009GL037308, 2009.

Brilli, F., Barta, C., Fortunati, A., Lerdau, M., Loreto, F., and Centritto, M.: Response of isoprene emission and carbon metabolism to drought in white poplar (Populus alba) saplings, New Phytol., 175, 244-254, 2007.
CARB: The Ozone Weekend Effect in California, California Air Reasearch Board Planning and Technical Support Division, 2003.

CDPHE: Denver Metro Area \& North Front Range Ozone Action Plan, Colorado Air Quality Control Commission Denver, CO, 2008.

CDPHE: For Recommended 8-Hour Ozone Designations, edited by: Environment, C. D. o. P. H. a., CDPHE, Denver, Colorado, 2009.

CDPHE: Control of Ozone Via Ozone Precursors and Control of Hydocarbons Via Oil and Gas Emissions, Colorado Air Quality Control Commission, Denver, CO, 2014.

CDPHE: Moderate area ozone SIP for the Denver Metro and North Front Range nonattaiment area, Colorado Air Quality Control Commission, Denver, CO, 2016.

Cleveland, W. S., Graedel, T. E., Kleiner, B., and Warner, J.: Sunday and workday variations in photochemical air pollutants in New Jersey and New York, Science, 186, 1037-1038, 1974.

Cooper, O., Parrish, D., Stohl, A., Trainer, M., Nédélec, P., Thouret, V., Cammas, J.-P., Oltmans, S., Johnson, B., and Tarasick, D.: Increasing springtime ozone mixing ratios in the free troposphere over western North America, Nature, 463, 344-348, 2010.

Cooper, O. R., Gao, R. S., Tarasick, D., Leblanc, T., and Sweeney, C.: Long-term ozone trends at rural ozone monitoring sites across the United States, 1990-2010, J. Geophys. Res.-Atmos., 117, https://doi.org/10.1029/2012JD018261, 2012.

Davis, J., Cox, W., Reff, A., and Dolwick, P.: A comparison of CMAQ-based and observation-based statistical models relating ozone to meteorological parameters, Atmos. Environ., 45, 34813487, 2011.

Dunlea, E. J., Herndon, S. C., Nelson, D. D., Volkamer, R. M., San Martini, F., Sheehy, P. M., Zahniser, M. S., Shorter, J. H., Wormhoudt, J. C., Lamb, B. K., Allwine, E. J., Gaffney, J. S., Marley, N. A., Grutter, M., Marquez, C., Blanco, S., Cardenas, B., Retama, A., Ramos Villegas, C. R., Kolb, C. E., Molina, L. T., and Molina, M. J.: Evaluation of nitrogen dioxide chemiluminescence monitors in a polluted urban environment, Atmos. Chem. Phys., 7, 2691-2704, https://doi.org/10.5194/acp-7-26912007, 2007.

Ek, M. and Holtslag, A.: Influence of soil moisture on boundary layer cloud development, J. Hydrometeorol., 5, 86-99, 2004.

EPA: National Ambient Air Quality Standards for Ozone; Propose Rule, EPA, 2014.

EPA: Ozone Trends: https://www.epa.gov/air-trends/ozone-trends (last access: 19 January 2017), 2016a.

EPA: Air Pollutants Emission Trends Data, available at: https://www.epa.gov/air-emissions-inventories/ air-pollutant-emissions-trends-data (last access: 19 January 2017), 2016b.

EPA: Air Quality System (AQS) and AQS Data Mart, available at: https://www3.epa.gov/ttn/airs/aqsdatamart/, last access: July 2016c.

Farmer, D. K., Perring, A. E., Wooldridge, P. J., Blake, D. R., Baker, A., Meinardi, S., Huey, L. G., Tanner, D., Vargas, O., and Cohen, R. C.: Impact of organic nitrates on urban ozone production, Atmos. Chem. Phys., 11, 4085-4094, https://doi.org/10.5194/acp11-4085-2011, 2011.

Fischer, E. V., Jacob, D. J., Yantosca, R. M., Sulprizio, M. P., Millet, D. B., Mao, J., Paulot, F., Singh, H. B., Roiger, A., 
Ries, L., Talbot, R. W., Dzepina, K., and Pandey Deolal, S.: Atmospheric peroxyacetyl nitrate (PAN): a global budget and source attribution, Atmos. Chem. Phys., 14, 2679-2698, https://doi.org/10.5194/acp-14-2679-2014, 2014.

Fortunati, A., Barta, C., Brilli, F., Centritto, M., Zimmer, I., Schnitzler, J. P., and Loreto, F.: Isoprene emission is not temperaturedependent during and after severe drought-stress: a physiological and biochemical analysis, Plant J., 55, 687-697, 2008.

Fujita, E. M., Stockwell, W. R., Campbell, D. E., Keislar, R. E., and Lawson, D. R.: Evolution of the magnitude and spatial extent of the weekend ozone effect in California's South Coast Air Basin, 1981-2000, J. Air Waste Manage. Assoc., 53, 802-815, 2003.

Gilman, J. B., Lerner, B. M., Kuster, W. C., and de Gouw, J. A.: Source signature of volatile organic compounds from oil and natural gas operations in northeastern Colorado, Environ. Sci. Technol., 47, 1297-1305, https://doi.org/10.1021/es304119a, 2013.

Guenther, A., Zimmerman, P., Klinger, L., Greenberg, J., Ennis, C., Davis, K., Pollock, W., Westberg, H., Allwine, G., and Geron, C.: Estimates of regional natural volatile organic compound fluxes from enclosure and ambient measurements, J. Geophys. Res.Atmos., 101, 1345-1359, 1996.

Guenther, A., Karl, T., Harley, P., Wiedinmyer, C., Palmer, P. I., and Geron, C.: Estimates of global terrestrial isoprene emissions using MEGAN (Model of Emissions of Gases and Aerosols from Nature), Atmos. Chem. Phys., 6, 3181-3210, https://doi.org/10.5194/acp-6-3181-2006, 2006.

Heuss, J. M., Kahlbaum, D. F., and Wolff, G. T.: Weekday/weekend ozone differences: what can we learn from them?, J. Air Waste Manage. Assoc., 53, 772-788, 2003.

IPCC: Climate Change 2014 - Impacts, Adaptation and Vulnerability: Regional Aspects, edited by: Change, I. P. o. C., Cambridge University Press, 2014.

Jacob, D. J. and Winner, D. A.: Effect of climate change on air quality, Atmos. Environ., 43, 51-63, 2009.

Lefohn, A. S., Shadwick, D., and Oltmans, S. J.: Characterizing changes in surface ozone levels in metropolitan and rural areas in the United States for 1980-2008 and 1994-2008, Atmos. Environ., 44, 5199-5210, 2010.

Lin, M., Fiore, A. M., Horowitz, L. W., Langford, A. O., Oltmans, S. J., Tarasick, D., and Rieder, H. E.: Climate variability modulates western US ozone air quality in spring via deep stratospheric intrusions, Nature Communications, 6, https://doi.org/10.1038/ncomms8105, 2015.

Lindaas, J., Farmer, D. K., Pollack, I. B., Abeleira, A., Flocke, F., Roscioli, R., Herndon, S., and Fischer, E. V.: The impact of aged wildfire smoke on atmospheric composition and ozone in the Colorado Front Range in summer 2015, Atmos. Chem. Phys. Discuss., https://doi.org/10.5194/acp-2017-171, in review, 2017.

Marr, L. C. and Harley, R. A.: Modeling the Effect of WeekdayWeekend Differences in Motor Vehicle Emissions on Photochemical Air Pollution in Central California, Environ. Sci. Technol., 36, 4099-4106, 2002.

McDonald, B. C., Gentner, D. R., Goldstein, A. H., and Harley, R. A.: Long-term trends in motor vehicle emissions in US urban areas, Environ. Sci. Technol., 47, 10022-10031, 2013.

McDuffie, E. E., Edwards, P. M., Gilman, J. B., Lerner, B. M., Dubé, W. P., Trainer, M., Wolfe, D. E., Angevine, W. M., deGouw, J., and Williams, E. J.: Influence of oil and gas emissions on sum- mertime ozone in the Colorado Northern Front Range, J. Geophys. Res.-Atmos., 121, 8712-8729, 2016.

Murphy, J. G., Day, D. A., Cleary, P. A., Wooldridge, P. J., Millet, D. B., Goldstein, A. H., and Cohen, R. C.: The weekend effect within and downwind of Sacramento - Part 1: Observations of ozone, nitrogen oxides, and VOC reactivity, Atmos. Chem. Phys., 7, 5327-5339, https://doi.org/10.5194/acp-7-5327-2007, 2007.

North American Drought Monitor: https://www.ncdc.noaa.gov/ temp-and-precip/drought/nadm/maps, last access: February 2017.

Palut, M. P. J. and Canziani, O. F.: Contribution of working group II to the fourth assessment report of the intergovernmental panel on climate change, Cambridge University Press, 2007.

Parrish, D., Dunlea, E., Atlas, E., Schauffler, S., Donnelly, S., Stroud, V., Goldstein, A., Millet, D., McKay, M., and Jaffe, D.: Changes in the photochemical environment of the temperate North Pacific troposphere in response to increased Asian emissions, J. Geophys. Res.-Atmos., 109, https://doi.org/10.1029/2004JD004978, 2004.

Pétron, G., Frost, G., Miller, B. R., Hirsch, A. I., Montzka, S. A., Karion, A., Trainer, M., Sweeney, C., Andrews, A. E., Miller, L., Kofler, J., Bar-Ilan, A., Dlugokencky, E. J., Patrick, L., Moore, C. T., Ryerson, T. B., Siso, C., Kolodzey, W., Lang, P. M., Conway, T., Novelli, P., Masarie, K., Hall, B., Guenther, D., Kitzis, D., Miller, J., Welsh, D., Wolfe, D., Neff, W., and Tans, P.: Hydrocarbon emissions characterization in the Colorado Front Range: A pilot study, J. Geophys. Res.-Atmos., 117, https://doi.org/10.1029/2011jd016360, 2012.

Pfister, G. G., Parrish, D. D., Worden, H., Emmons, L. K., Edwards, D. P., Wiedinmyer, C., Diskin, G. S., Huey, G., Oltmans, S. J., Thouret, V., Weinheimer, A., and Wisthaler, A.: Characterizing summertime chemical boundary conditions for airmasses entering the US West Coast, Atmos. Chem. Phys., 11, 1769-1790, https://doi.org/10.5194/acp-11-1769-2011, 2011.

Pollack, I., Ryerson, T., Trainer, M., Parrish, D., Andrews, A., Atlas, E. L., Blake, D., Brown, S., Commane, R., and Daube, B.: Airborne and ground-based observations of a weekend effect in ozone, precursors, and oxidation products in the California South Coast Air Basin, J. Geophys. Res.-Atmos., 117, https://doi.org/10.1029/2011JD016772, 2012.

Pusede, S. E. and Cohen, R. C.: On the observed response of ozone to $\mathrm{NO}_{x}$ and VOC reactivity reductions in San Joaquin Valley California 1995-present, Atmos. Chem. Phys., 12, 8323-8339, https://doi.org/10.5194/acp-12-8323-2012, 2012.

Pusede, S. E., Gentner, D. R., Wooldridge, P. J., Browne, E. C., Rollins, A. W., Min, K.-E., Russell, A. R., Thomas, J., Zhang, L., Brune, W. H., Henry, S. B., DiGangi, J. P., Keutsch, F. N., Harrold, S. A., Thornton, J. A., Beaver, M. R., St. Clair, J. M., Wennberg, P. O., Sanders, J., Ren, X., VandenBoer, T. C., Markovic, M. Z., Guha, A., Weber, R., Goldstein, A. H., and Cohen, R. C.: On the temperature dependence of organic reactivity, nitrogen oxides, ozone production, and the impact of emission controls in San Joaquin Valley, California, Atmos. Chem. Phys., 14, 3373-3395, https://doi.org/10.5194/acp-143373-2014, 2014.

Reddy, P. J. and Pfister, G. G.: Meteorological factors contributing to the interannual variability of mid-summer surface ozone in 
Colorado, Utah, and other western US states, J. Geophys. Res.Atmos., 121, https://doi.org/10.1002/2015JD023840, 2016.

Singh, H. B. and Hanst, P. L.: Peroxyacetyl nitrate (PAN) in the unpolluted atmosphere: An important reservoir for nitrogen oxides, Geophys. Res. Lett., 8, 941-944, 1981.

Swarthout, R. F., Russo, R. S., Zhou, Y., Hart, A. H., and Sive, B. C.: Volatile organic compound distributions during the NACHTT campaign at the Boulder Atmospheric Observatory: Influence of urban and natural gas sources, J. Geophys. Res.-Atmos., 118, 10614-10637, https://doi.org/10.1002/jgrd.50722, 2013.

Tai, A. P., Martin, M. V., and Heald, C. L.: Threat to future global food security from climate change and ozone air pollution, Nature Climate Change, 4, 817-821, 2014.

Thompson, C. R., Hueber, J., and Helmig, D.: Influence of oil and gas emissions on ambient atmospheric nonmethane hydrocarbons in residential areas of Northeastern Colorado, Elementa: Science of the Anthropocene, 2, 000035, https://doi.org/10.12952/journal.elementa.000035, 2014.

Thompson, M. L., Reynolds, J., Cox, L. H., Guttorp, P., and Sampson, P. D.: A review of statistical methods for the meteorological adjustment of tropospheric ozone, Atmos. Environ., 35, 617630, 2001

US-Energy Information Administration: Natural Gas - Data, available at: https://www.eia.gov/, last access: April 2017.
Warneke, C., Gouw, J. A., Edwards, P. M., Holloway, J. S., Gilman, J. B., Kuster, W. C., Graus, M., Atlas, E., Blake, D., and Gentner, D. R.: Photochemical aging of volatile organic compounds in the Los Angeles basin: Weekday-weekend effect, J. Geophys. Res.Atmos., 118, 5018-5028, 2013.

Weiss-Penzias, P., Jaffe, D. A., Swartzendruber, P., Dennison, J. B., Chand, D., Hafner, W., and Prestbo, E.: Observations of Asian air pollution in the free troposphere at Mount Bachelor Observatory during the spring of 2004, J. Geophys. Res.-Atmos., 111, https://doi.org/10.1029/2005JD006522, 2006.

White, A., Darby, L., Senff, C., King, C., Banta, R., Koermer, J., Wilczak, J., Neiman, P., Angevine, W., and Talbot, R.: Comparing the impact of meteorological variability on surface ozone during the NEAQS (2002) and ICARTT (2004) field campaigns, J. Geophys. Res.-Atmos., 112, https://doi.org/10.1029/2005JD006522, 2007.

Zhou, X. and Geerts, B.: The influence of soil moisture on the planetary boundary layer and on cumulus convection over an isolated mountain. Part I: observations, Mon. Weather Rev., 141, 10611078, 2013. 